\author{
Anna ADAMUS-MATUSZYŃSKA, PhD \\ College of Economics, University of Economics in Katowice \\ e-mail: anna.adamus-matuszyńska@ue.katowice.pl \\ ORICD: 0000-0003-3234-4599
}

DOI: $10.15290 /$ oes.2020.03.101.07

\title{
HEURISTICS AND BIASES AS SOURCES OF NEGOTIATORS' ERRORS IN THE PRE-NEGOTIATION PHASE. REVIEW OF LITERATURE AND EMPIRICAL RESEARCH ${ }^{1}$
}

\begin{abstract}
Summary
Purpose - Heuristics and biases are simplifying strategies that people (in the analysed issue negotiators) use in the decision-making process, even when they can take advantage of supporting tools (e.g. Negotiation Support System), which will allow them to make the optimal choice [Wachowicz, 2006]. Many empirical studies have found that decision makers use heuristics and are biased [Bateman, Zeithaml, 1989; Jackson, Dutton, 1988; Kahneman et al. 1982; Zajac, Bazerman, 1991]. Therefore, the question should be asked: are negotiators, like managers (whose decisions were examined), instead of consciously and intentionally using tools supporting decision-making during negotiations, subject to heuristics and cognitive errors? As a consequence of this general question one may ask the specific research questions: (1) What heuristics do the negotiators undergo? (2) How do heuristics influence the decision-making process? (3) How can the impact of heuristics and biases be minimized by taking advantage of negotiation support tools?

Research methods - The article is a review of psychological, sociological and management sciences theories, concepts and empirical researches on heuristics and biases. The review was made according to the following categories: (a) theories that recognize the inevitability of heuristics in the decision-making process, (b) theories that attempt to identify opportunities to minimize or even reduce the impact of heuristics on decisions, and (c) those that offer alternative solutions.

Results - The summary highlights those heuristics which might occur in the decision-making process in the pre-negotiation phase.

Originality/value - There is no research exploring the role of specific heuristics and biases in particular stages of negotiations.
\end{abstract}

Keywords: heuristics, biases, negotiation, pre-negotiation phase

JEL Classification: D03

${ }^{1}$ Article received on 06 January 2020, accepted on 20 April 2020.

Research carried out as part of a research project No. 2016/21/B/HS4/01583 "Support for bilateral negotiations, taking into account heuristic thinking and cognitive limitations of negotiators" (Agreement No. UMO-2016/21/B/ HS4/01583). 


\section{Introduction}

Since the Enlightenment, it has been assumed that a person is a rational being, which has been so far the principal for scientific researches in social sciences as well as decision-making theories. However, since Herbert Simon's [1955, 1982] theory of bounded rationality was published, research on the decision making process has often involved deviations from rational choice, regardless of whether they are defined as shortcomings in human reasoning or as adaptive strategies. The research and theory of Tversky and Kahneman [1974] regarding human judgments made under uncertainty focused on understanding heuristics and biases in assessing the likelihood of a particular phenomenon. Since that time, studies on this issue have covered fields such as behavioural economics and management sciences.

Cognitive tendencies are systematic deviations from rational decision-making resulting from the use of one or more heuristics. The term 'heuristics' is used to describe simplifying strategies [Gigerenzer et al., 1999] that people (in this case - negotiators) use to make decisions, even when they can use supportive tools (e.g., Negotiation Support System). Many empirical studies have found that most managers use heuristics and biases for a significant amount of time [Bateman, Zeithaml, 1989; Jackson, Dutton, 1988; Kahneman et al. 1982; Zajac, Bazerman 1991]. Therefore, the question may be asked: are the negotiators, like the managers (whose decisions were examined) instead of using the tools supporting the decision-making process available in the pre-negotiation phase, subject to heuristics and through their influence make mistakes not achieving the most optimal solution at the moment of the negotiation?

Heuristics were called 'the rules of thumb' by the Nobel laureate Richard H. Thaler [2018, p. 42], which help people assess the situation. These are informal, speculative, simplified methods of problem solving and decision making [Nęcka et al., 2006, p. 440] allowing for quick and effective judicial decisions [Aronson et al., 1997, p. 148]. Their main features are that they are unreliable and also increase the risk that results from the use of simplifications and schemes. Algorithms are an alternative to heuristics, i.e. unambiguous and reliable rules of operation, containing a finite sequence of operations to be undertaken to achieve a specific goal [Nęcka et al., 2006, p. 439]. The problem of heuristics and biases seems much more complex when one analyses the relationship of thinking and other cognitive processes, such as reasoning, problem solving or decision making. There are many recognised heuristics in human thinking such as solving heuristics (difference heuristics, a method of moving backwards, goals decomposition heuristics), judgment heuristics (representativeness heuristics, accessibility heuristics, anchoring and adjustment heuristics), decision making heuristics (satisficing strategy, elimination by aspect, heuristics "take the best", "take the last"). Thanks to them, the human mind adapts to the requirements [Nęcka et al., 2006, p. 578].

The use of schemes and heuristics in each of the processes: implication, judgments, decision making or problem-solving leads to mistakes, but it is functional and convenient for the human mind, so eliminating them is a challenge. However, 
it must be emphasised that heuristics are cognitive errors, which - knowing their features, origins, and triggers - can be predicted.

The purpose of the presented analysis is to review known and researched heuristics that may occur in the pre-negotiation phase and thus affect the negotiator's decision-making process and result in errors and simplifications.

Negotiation is an interactive decision-making process characterized by mutual dependence of partners, communication between them, and exchange of value [Kozina, 2015, p. 32]. The issue of heuristics' impact on negotiation is not widely analysed in the literature, it can even be said that there is a certain research gap regarding the issue of cognitive simplifications occurring in negotiation processes [Caputo, 2013, p. 375].

\section{Heuristics and cognitive errors in decision making - a review}

Assessing, reasoning, making decisions, solving problems in situations of uncertainty are complicated tasks for human cognition [Gilovich, Griffin, 2002]. That is why the human mind uses simplified thinking methods, thanks to which people make generalizations, assess others, make judgments or make comparisons.

The three heuristics - availability, representativeness, anchoring and adjustment - examined by Tversky and Kahneman are the main examples of sources of human cognitive errors that are very difficult to eliminate. While getting to know the surrounding world people use schemas - organized and simplified fragments of knowledge about people, situations, organizations and things, as well as methods that allow them to quickly and efficiently form judgments about the surrounding world and people - in order to facilitate this process. Some characteristic features of these processes are their usefulness and practicality, but as a consequence also the falsity of opinions and judgments based on them. Tversky and Kahneman said that these three heuristics explain the assessments of the probability and/or frequency of a given phenomenon that people make. These cognitive biases are not random mistakes, but they result from certain patterns. They have empirically proven that unlimited rationality does not work in practice. Empirical studies have shown that there is no perfect model for rational decision making.

Other heuristics featured in numerous psychologists' studies include [Caputo, 2013]:

- heuristics of recognition that occurs when people use selective data to confirm that a variable is present [Baron et al., 1988; Klayman, Ha, 1987];

- affect heuristics which are based on the fact that the judgments are grounded mainly in the emotional evaluation that takes place before the rational analysis [Kahneman, 2003];

- bounded awareness affects the information selection process: in order to avoid information overload people often filter it unconsciously [Bazerman, Chung, 2005];

- $\quad$ risk aversion relates to the fact that individuals treat profit-related risk gains differently from risk related to perceived losses [Tversky, Kahneman, 1979]; 
- the emotions of the individual can lead to biases and prejudices in connection with positive and negative moods. Studies show that good mood and happiness increases the role of heuristics [Alloy, Abramson, 1979; Bodenhausen et al., 1994], while negative mood reduces the dependence on stereotypes or heuristics [Park, Banaji, 2000].

The Nobel laureates met with criticism of their approach. One of their critics is Gigerenzer [1996], who assumes that the human mind can effectively use heuristics to draw conclusions, because simple heuristics also lead to correct and valuable findings. This is a positive approach to heuristics, in contrast to the approaches of Tversky and Kahneman, for whom heuristics are rather a burden on thinking [Gigerenzer et.al., 1999]. Heuristics are an indispensable tool of cognition, which lets a person not only orientate themselves in the huge amount of information that flows into the human mind and to adapt to the environment, but also to make decisions that can be called 'reasonable'. As a result of heuristic thinking, people make also correct or partially correct judgments, and that is why they accept it [Bazerman, Moore, 2009].

\section{Heuristics and cognitive biases - methods of elimination or reduction}

The scientific literature distinguishes two systems that interact with and influence peoples' behaviours and thoughts: (1) thinking and (2) feeling [ung, 1969, p. 117] or (1) analytical-rational and (2) intuitive-experiential [Epstein et al., 1996] or (1) intuitive and automatic and (2) reflective and rational [Thaler, Sunstein, 2017, p. 34] or, in other words, - (1) systematic (meaning: purposeful, conscious, methodical) and (2) heuristic (meaning: automatic, unconscious, disorganized), or in other words: System 1 (fast thinking) and System 2 (slow thinking) - names proposed by Stanovich and West [2008], and used by Kahneman [Kahneman, 2012, p. 31]. In general, both processes differ significantly, but they are not mutually exclusive. Fast, automatic and effortless thinking is obviously contrasted with slow, sequential and controlled thinking. The theory of two types of thinking emphasizes that these two processes are independent sources of control of behaviour that may interfere with each other. These two modes of thinking are named by researchers and simultaneously analysed in a variety of ways. And so, Epstein [1994] defines them as empirical-rational cognitive processes, Evans [1989] - heuristic-analytical, Chen and Chaiken [1999] - heuristic-systematic, Stanovich [1999] as system 1 and system 2, and Kahneman [2012] - fast thinking and slow thinking. The duality in distinguishing types of human thinking is characteristic for the history of psychological thought. Berlyne [1969] distinguished autistic and realistic thinking, the first loose and free, the second - focused on a specific goal. Selz [1922] divided the human thinking into productive one - creating new intellectual content and reproductive reconstructing past experience. The theory of persuasion recognizes that heuristic thinking takes place primarily in situations where people are unmotivated or otherwise unable to think logically; in contrast to systematic thinking, which can occur in 
situations where people are motivated and able to analyse information [Chaiken, 1987; Reimer, Hoffrage, 2012]. Chaiken's concept - heuristic-systematic model (HSM) - assumes that a person's need for accurate and complete information to achieve a high level of trust is a sufficient motivator to prefer systematic thinking [Eagly, Chaiken, 1993]. What is more, this concept assumes that heuristic processing of information requires less effort, and that is why many people make judgments and make decisions by using superficial guidelines, such as the message length, statistical data, or the use of a popular person. However, as emphasized by Bazerman and Moore [2009, p. 4], even when the individual uses only System 2, the intuitive System 1 affects the process of rational thinking through certain mental shortcuts [Evans, Stanovich, 2013]. As a result, both systems often work simultaneously affecting each other.

Thaler and Sunstein [2017, p. 33] argue that we use cognitive biases systematically, and our behaviour can be improved by realizing which ones and under what circumstances we use. Today, there are many tools supporting negotiators in the decision-making process. As studies show, however, they do not sufficiently support this process and negotiators still make mistakes resulting from their heuristic thinking [Wachowicz, Roszkowska, 2019]. Negotiation analysts are looking for factors determining the decision-making process that may affect heuristic thinking [Wachowicz et al., 2019]. That is why, it is so important to recognize all possible cognitive biases [Bazerman, Moore, 2009] to analyse the circumstances when they dominate and thus, formulate recommendations that will let us eliminate them, or at least minimize their negative impact on the decision-making process.

\section{The model of minimizing the negative impact of heuristics on the pre-negotiation phase}

Probabilistic theories and behavioural economics have introduced into psychological considerations the belief that by using equations (algorithms) one can not only rearrange, but also in a particular sense 'program' people's behaviour [Gigerenzer et al., 1999]. This led to the theory of bounded rationality, which assumes that we are able to behave in a rational manner, which can be simply defined using mathematical formulas and models. However, Simon [1995] saw at least two factors that favour bounded rationality rather than help its boundlessness. These are: the limitations of the human mind and the structure of the environment in which this mind is located. The theory of rationality is to provide the basis for the theory of human behaviour or of the social group who makes decisions. Economic theories and administration theories try to deal with human behaviour in situations where such behaviour is intentionally rational. However, when you replace a rational man with a person with limited knowledge and abilities, another concept arises revealing the discrepancy between the simplified model of rationality and reality. As Simon [1990] writes, because of the limitations of the human mind, people generalise to deal with daily routines. Our rationality is limited and in order to overcome its limi- 
tations, it is necessary to build the theory of process systems and describe the environments to which it adapts [Simon, 1990, p. 7]. Given these assumptions, Gigerenzer and et. al [1999] proposed a research project analysing the rational limitation of heuristics. It consists of: (a) designing computational models, (b) analysing the environmental structure, (c) testing results in the real world, (d) determining when and where people use these heuristics. This model is consistent. However, it requires the preparation of a data set, its development and indication of the possibilities of use.

Negotiators, like all people, are subject to heuristics, as highlighted above, but also to the processes of using heuristics in the negotiation process by their opponents. According to research [Gigerenzer, 1996], heuristics do not have to have a negative impact on the decisions made, although so far, most studies underline this aspect. Simplifications and mental shortcuts are useful in some situations. However, it is extremely difficult to determine the conditions for the positive use of heuristics. That is why, in the analysis of heuristics in the pre-negotiation phase, a hypothetical assumption resulting from previous experiments [Kersten et al., 2017, p. 216] was adopted stating that heuristics determine making mistakes despite the provided negotiation support system.

The pre-negotiation phase consists of three stages [Michnik, Wachowicz, 2016, p. 49]:

(1) inal preparation,

(2) joint preparation,

(3) individual analysis of the common vision of the problem (individual repreparationdividu

In the first stage (1), during which the negotiators organize the available information individually and create a vision of the negotiation process, there occurs the strongest influence of heuristics, because this stage is strongly dependent on personal characteristics (temperament, IQ, EQ, personality, past experience, willpower) of the negotiators, and they are important for the level of susceptibility to heuristics [Bazerman, Moore, 2009]. Therefore, during the period of individual preparation for negotiations, the negotiators, similarly to managers assessing their employees, rely primarily on their memory, which recalls above all common, previously experienced and repetitive cases [Bazerman, Moore, 2009, p. 19]. Hence at this stage studies on the susceptibility to heuristics is required, because hypothetically one can only assume its strong influence. Risk aversion is another simplification that should be considered at this stage of pre-negotiation and it results from the negotiators' personal characteristics. We know from the research of Tversky and Kahneman that individuals are guided by risk aversion in the area of profit, while in the area of loss they are characterized by risk propensity. Empirical studies also show that there are differences in risk tendency between women and men [Piktus, Czerwonka, 2018]. It can, therefore, be assumed that the analysis of risk and possible losses will depend on the negotiator's inclination to succumb to this cognitive error.

In the second stage (2), there occur interactions between the negotiators, which have mutual influence resulting from: the overlap of each negotiator's social systems [Luhman, 1996], the impact of differences in personal characteristics and differences 
in the approach to the previously developed vision of the negotiation process. Heuristics of representativeness will have an important role at this stage, because negotiators need to organize knowledge about themselves, to make joint arrangements, consciously or unconsciously affecting each other. When there are no precise descriptions of the members of a negotiating group, people tend to assign a given person to a larger group because they have one or two characteristics of such a group. Studies have shown that in such a situation we ignore individual features, even when information about them is available [Bazerman, Moore, 2009, p. 22], and we give in to representativeness heuristics by classifying a particular person as belonging to a group known to have similar features. Working together with other people means that we are more often subject to anchoring and adjustment heuristics, because in order to evaluate an issue we reach for information (anchor) we previously had on this topic, and then are guided by the information in the selection of the new incoming data [Epley, Gilovich, 2006]. At this stage of negotiation, the first offer is prepared, which through the anchoring effect affects the final result of the negotiations [Roszkowska, 2016, p. 147]. When new information provided by others is inconsistent with the previous one, this heuristic causes us to reject it, only because of incompatibility, but not because of assessing its credibility.

CHART 1

Types of heuristics at particular stages of the pre-negotiation phase
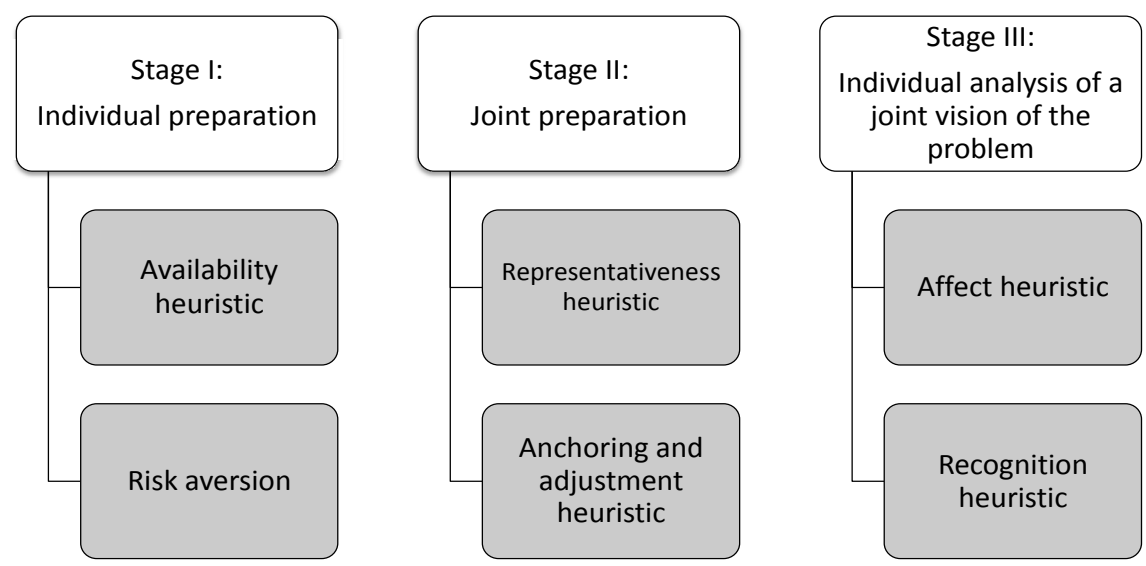

Source: author's own work.

In the third stage (3), during which the negotiating problem is revised, and an individual system of preferences is developed, an analysis of the environmental structure in which the negotiations take place will play an important role [Bazerman, Neale, 1983]. It can be assumed that this is a stage in which emotions play a special role due to the need to choose the negotiator's preferences, and preferences arouse emotions. Simon [1983, p. 30] has already written about the importance of emotions in the decision-making process, stating that emotions cannot be separated from 
human thinking, nor can their influence on the decision-making process be underestimated. When making decisions, people refer to a certain set of affects containing positive and negative references related to the subject of the decision [Slovic et al., 2007, p. 1335]. Empirical studies have shown that affect heuristics determine perception of risk and perception of benefits [Alhakami, Slovic, 1994]. The revision of the negotiating problem is also associated with the need to select arguments. At this point, it should be noted that recognition heuristic will have an impact, which means that the decision maker considers the fact he/she already knows as more important [Goldstein, Gigerenzer, 2002], and reduces the importance of the new, less known arguments.

The indicated heuristics are only examples of those that occur in the decisionmaking process and it has been hypothetically accepted that at particular stages of the pre-negotiation phase they can have an impact on cognitive biases made by negotiators. Taking into account Thaler's thesis, the first step to reduce the negative impact of heuristics on negotiators will be to indicate where and when there is a likelihood of heuristics having a negative impact on their job (chart 1). The model shown results from psychosocial conditions relevant to the pre-negotiation phase. This is a preliminary model that requires enhancement, testing and verification.

\section{Conclusions}

The choice of heuristics presented above, which can determine the negotiators' decision-making process in the pre-negotiation phase, is selective because it results only from a review of theoretical and empirical literature. The presented considerations discuss only a few heuristics; however, further theoretical, empirical and experimental research might reveal the influence of other heuristics. For example, in experimental studies, the tendency to use round numbers heuristics in the reconstruction of the principals' preference values has been identified [Kersten et al., 2018]. As heuristics researchers explain, they can have both positive and negative impact on the negotiating decision-making process. Positive, because they speed up this process, negative, because they can lead people to wrong decisions. Negotiators are likely to succumb to all cognitive errors, but the specificity of the various stages of negotiation affects the importance of some heuristics, and the invalidity of others. No method has been found so far to eliminate the influence of heuristics. Neither the negotiator's intelligence, nor his/her competent knowledge will protect them from their influence. However, this does not mean that one should abandon research and look for a way to eliminate those that have a particularly negative impact on the negotiator. That is why, it is so important to recognize heuristics and to determine the negotiator's predisposition to succumb to heuristics, in order to provide such tools that will optimize the decision-making process. Reducing the impact of heuristics in the pre-negotiation phase will result in better negotiation in the phase of the direct contact with opponents. 


\section{References}

Alhakami A.S., Slovic P., 1994, A psychological study of the inverse relationship between perceived risk and perceived benefit, "Risk Analysis", no. 14 (6), p. 1085-1096, DOI: 10. 1111/j.1539-6924.1994.tb00080.x.

Alloy L.B., Abramson L.Y., 1979, Judgment of contingency in depressed and nondepressed students: sadder but wiser? "Journal of Experimental Psychology: General", vol. 108, pp. 441-485.

Aronson E., Wilson T.D., Akert R.M., 1997, Psychologia społeczna. Serce i umyst. Wydawnictwo Zysk i S-ka, Poznań.

Baron J., Beattie J., Hershey J., 1988, Heuristics and biases in diagnostic reasoning: II. congruence, information, and certainty, "Organizational Behavior and Human Decision Processes”, vol. 42(1), pp. 88-110, DOI: 10.1016/0749-5978(88)90021-0.

Bateman T.S., Zeithaml C.P., 1989, The psychological context of strategic decisions: A model and convergent experimental findings, "Strategic Management Journal", vol. 10(1), pp. 59-74, DOI: 10.1002/smj.4250100106.

Bazerman M.H., Neale M.A., 1983, Heuristics in negotiation: Limitations to effective dispute resolution, [in:] Negotiating in organizations, Bazerman M.H., Lewicki R.J. (eds.), Sage, Beverly Hills, CA.

Bazerman M.H., Chung D., 2005, Focusing in negotiation, [in:] Frontiers of Social Psychology: Negotiations, Thompson L. (ed.), Psychological Press, New York.

Bazerman M.H., Moore D., 2009, Judgment in Managerial Decision Making, Wiley, New Caledonia.

Berlyne D.E., 1969, Struktura i kierunek myślenia, Wydawnictwo PWN, Warszawa.

Bodenhausen G.V., Kramer G.P., Suesser K., 1994, Happiness and stereotypic thinking in social judgment, "Journal of Personality and Social Psychology", vol. 66(4), pp. 621-632, DOI: 10.1037/0022-3514.66.4.621.

Caputo A., 2013, A literature review of cognitive biases in negotiation processes, "International Journal of Conflict Management”, vol. 24 (4), pp. 374-398, DOI: 10.1108/ IJCMA-08-2012-0064.

Chaiken S., 1987, The heuristic model of persuasion, [in:] Ontario symposium on personality and social psychology. Social influence: The Ontario symposium, Zanna M.P., Olson J.M., Herman C.P. (eds.), vol. 5, pp. 3-39.

Chen S., Chaiken S., 1999, The heuristic-systematic model in its broader context, [in:] Dualprocess theories in social psychology, Chaiken S., Trope Y. (eds.), The Guildford Press, New York.

Eagly A.H., Chaiken S., 1993, The psychology of attitudes, Fort Worth, TX: Harcourt Brace and Jovanovich.

Epley N., Gilovich T., 2006, The Anchoring-and-Adjustment Heuristic. Why the Adjustments Are Insufficient, "Psychological Science", vol. 17(4), p. 311-318.

Epstein S., 1994, Integration of the cognitive and psychodynamic unconscious, "American Psychologist", no. 49, p. 709-724, DOI: 10.1037//0003-066X.49.8.709. 
Epstein S., Pacini R., Denes-Raj V., Heier H., 1996, Individual differences in intuitive-experimental and analytical-rational thinking styles, "Journal of Personality and Social Psychology”, vol. 71(2), pp. 390-405, DOI: 10.1037/0022-3514.71.2.390.

Evans J.S.B.T., 1989, Bias in human reasoning: Causes and consequences, Brighton, England: Erlbaum.

Evans J.S.B.T, Stanovich K.E., 2013, Dual-Process Theories of Higher Cognition: Advancing the Debate, "Perspectives on Psychological Science", vol. 8(3), p. 223-241, DOI: $10.1177 / 1745691612460685$.

Gigerenzer G., Todd P.M., ABC Research Group, 1999, Simple Heuristics That Make Us Smart, Oxford University Press, Oxford.

Gigerenzer G., 1996, On narrow norms and vague heuristics: A reply to Kabneman and Tversky, "Psychological Review", vol. 103(3), pp. 592-596.

Gilovich T., Griffin D., 2002, Introduction - Heuristics and Biases: Then and Now, [in:] Heuristics and biases: The Psychology of Intuitive Judgment, Gilovich T., Griffin D., Kahneman D. (eds.), Cambridge University Press, Cambridge.

Goldstein D.G., Gigerenzer G., 2002, Models of ecological rationality: The recognition heuristic, "Psychological Review", vol. 109, pp. 75-90, DOI: 10.1037//0033-295X. 109.1.75.

Jackson S.E., Dutton J.E., 1988, Discerning Threats and Opportunities, "Administrative Science Quarterly”, no. 33(3), pp. 370-387, DOI: 10.2307/2392714.

Jung C.G., 1969, The Psychology of the Transference, Routledge, London.

Kahneman D., Slovic P., Tversky A., 1982, Judgment under uncertainty: Heuristics and biases, Cambridge University Press, Cambridge.

Kahneman D., 2003, A perspective on judgment and choice: mapping bounded rationality, “American Psychologist", vol. 58(9), pp. 697-720, DOI: 10.1037/0003-066X.58. 9.697.

Kahneman D., 2012, Pułapki myślenia. O myśleniu ssybkim i wolnym, Media Rodzina, Poznań.

Kersten G.E., Roszkowska E., Wachowicz T., 2017, The heuristics and biases in using the negotiation support systems, [in:] Group Decision and Negotiation. A Socio-Technical Perspective, Schoop M, Kilgour D.M. (eds.), 17th International Conference, Stuttgart, Germany, Proceedings, pp. 215-228.

Kersten G.E., Roszkowska E., Wachowicz T., 2018, Representative Decision-Making and the Propensity to Use Round and Sharp Numbers in Preference Specification, [in:] Group Decision and Negotiation in an Uncertain World, Chen Y., Kersten G., Vetschera R., $\mathrm{Xu}$ H. (eds), Lecture Notes in Business Information Processing, vol 315, pp. 43-55.

Klayman J., Ha Y.W., 1987, Confirmation, disconfirmation, and information in hypothesis testing, "Psychological Review", vol. 94(2), pp. 211-228, DOI: 10.1037/0033-295X.94.2.211.

Kozina A., 2015, Dobór technik, prowadzenia negocjaci, „Zeszyty Naukowe Uniwersytetu Ekonomicznego w Krakowie", vol. 8(944), pp. 31-44, DOI: 10.15678/ZNUEK. 2015.0944.0803.

Luhmann N., 1996, Social Systems, Stanford University Press, Stanford.

Michnik J., Wachowicz T., Definicja problemu negocjacyjnego, [in:] Negocjacje. Analiza i wspomaganie decyzji, Roszkowska E., Wachowicz T., Wolters Kluwer, Warszawa. 
Nęcka E., Orzechowski J., Szymura B., 2006, Psychologia poznawrza, Wydawnictwo Naukowe PWN, Warszawa.

Park J., Banaji M.R., 2000, Mood and heuristics: the influence of happy and sad states on sensitivity and bias in stereotyping, "Journal of Personality and Social Psychology", vol. 78(6), pp. 1005-1023, DOI: 10.1037//0022-3514.78.6.1005.

Piktus K., Czerwonka M., 2018, Awersja do strat i uybrane znieksztatcenia poznawcze w kontekśscie różnic mięsyplcionych, „Studia i Prace Kolegium Zarządzania i Finansów", z. 164, pp. 25-47.

Reimer T., Hoffrage U., 2012, Simple Heuristics and Information Sharing in Groups, [in:] Simple Heuristics in a Social World, Hertwig R., Hoffrage U., ABC Research group (eds)., Oxford University Press, New York, DOI:10.1093/acprof:oso/97801953 88435.003.0011.

Roszkowska E., 2016, Mo:̀liwosíc wykoraystania systemu oceny ofert negocjacyjnych do wspomagania procesu negocjacji, [in:] Negocjacje. Analiza i wspomaganie decyzji, Roszkowska E., Wachowicz T., Wolters Kluwer, Warszawa.

Selz O., 1922, Zur Psychologie der produktiven Denkens und des Irrtums (On the psychology of productive thinking and of error), Cohen, Bonn.

Simon H.A., 1955, A Behavioral Model of Rational Choice, "The Quarterly Journal of Economics", vol. 69(1), pp. 99-118, DOI: 10.2307/1884852.

Simon H.A., 1982, Models of bounded rationality, MA: MIT Press, Cambridge.

Simon H.A., 1983, Reason in Human Affairs, Stanford University Press PY, Stanford.

Simon H.A., 1990, Invariants of Human Behavior, "Annual Review of Psychology", no. 41, pp. 1-19.

Slovic P., Finucane M.L., Peters E., MacGregor D.G., 2007, The affect heuristic, "European Journal of Operational Research", vol. 177, p. 1333-1352, DOI: 10.1016/ j.ejor.2005.04.006.

Stanovich K.E., 1999, Who is Rational? Studies of Individual Differences in Reasoning. Psychology Press, New York.

Stanovich K.E., West R. F., 2008, On the relative independence of thinking biases and cognitive ability, "Journal of Personal Social Psychology", vol. 94(4), pp. 672-695, DOI: 10.1037/0022-3514.94.4.672.

Thaler R.H., Sunstein C.R., 2017, Impuls. Jak podejmować właściwe decyæje dotyczqce zdrowia, dobrobytu i szczésicia, Wydawnictwo Zysk i S-ka, Poznań.

Thaler R.H., 2018, Zachowania niepoprawne. Tworzenie ekonomii behawioralnej, Media Rodzinna, Poznań.

Tversky A., Kahneman D., 1974, Judgment under Uncertainty: Heuristics and Biases. "Science", vol. 185(4157), pp. 1124-1131, DOI: 10.1126/science.185.4157.1124.

Tversky A., Kahneman D., 1979, Prospect theory: an analysis of decision under risk, "Econometrica", vol. 47(2), pp. 263-291.

Wachowicz T., 2006, E-negocjacje, modelowanie, analiza i wspomaganie, Wydawnictwo Akademii Ekonomicznej, Katowice.

Wachowicz T., Roszkowska E., Filipowicz-Chomko M., 2019, Decision Making Profile and the Choices of Preference Elicitation Mode - A Case of Using GDMS Inventory, Proceedings The 15th International Symposium on Operational Research, pp. 72-77. 
Wachowicz T., Roszkowska E., 2019. Investigating the Self-Serving Bias Software Supported Multiple Criteria Decision-Making Process, Proceedings The 15th International Symposium on Operational Research, pp. 66-71.

Zajac E J., Bazerman M.H., 1991, Blind Spots in Industry and Competitor Analysis: The Implications of Interfirm (Mis)perceptions for Strategic Decisions, "The Academy of Management Review”, vol. 16(1), pp. 37-56, DOI: 10.2307/258606. 